\title{
sciforum
}

Conference Proceedings Paper

\section{Adaptation strategies of the hydrosocial cycles in the Mediterranean regions}

\author{
Ana Arahuetes ${ }^{1,}$, , María Hernández ${ }^{1}$ and Antonio M. Rico ${ }^{1}$ \\ Published: 05/11/2017 \\ Academic Editor: Sergio Vicente-Serrano \\ 1 Interuniversity Institute of Geography, University of Alicante, Ctra. San Vicente del Raspeig s/n, 03690, San \\ Vicente del Raspeig (Alicante); maria.hernandez@ua.es (M.H.); am.rico@ua.es (A.M.R) \\ * Correspondence: ana.arahuetes@ua.es ; Tel.: +34-965903426
}

\begin{abstract}
The Spanish Mediterranean regions have been affected by several factors over the years (climatic conditions of aridity, high demands, quick and intense urban and population growth, climate change), which that have generated a negative water balance in which water contributions are unable to meet the demands. The aim of this paper is to evaluate the adaptation strategies that have been developed in these cities in order to adjust their hydrosocial cycles to development and future scenarios. Diversifying supply sources by resorting to new resources has been a necessity that has stimulated the expansion and integration of non-conventional water sources (desalination and the reuse of reclaimed water) and sustainable solutions. The theoretical analysis developed in this paper is corroborated by the study of the hydrosocial cycle evolution of three cities in the Southeast of Spain, and the adaptive measures that the different actors involved in the cycle have developed in each of them. The input and output are taken into account in this system thanks to the information provided by the management companies in each of the phases (urban consumption, treated and reused volumes, desalinated volumes), which highlight how the diversification of resources and the incorporation of non-conventional resources have been essential for adaptation.
\end{abstract}

Keywords: water deficit; hydrosocial cycles; adaptation; diversification; non-conventional resources; Mediterranean regions

\section{Introduction}

Despite the fact that water has been conceived as being an unlimited resurgent resource throughout history, since the middle of the $20^{\text {th }}$ century it has been considered as being a natural, economic and social asset of limited and limiting value [1,2]. Specifically in the Mediterranean region of Spain this resource has become remarkably important for the socio-economic development of the area, mainly for the tourism and agricultural sector [3]. This scarce asset acquires greater importance in areas whose water contributions fail to meet the demands, a situation that occurs in Spain, especially on the Mediterranean coast, in the Canary Islands and the Balearic Islands.

A good example of this is the province of Alicante, located in the southeast of the Iberian Peninsula, which is characterized by less than $300 \mathrm{~mm}$ of rainfall a year, despite having high agricultural and urban-tourism water demands [4]. These factors have generated a water deficit that, by the year 2016, was around $200 \mathrm{hm}^{3}$ [5]. This water shortage is expected to increase in the future, considering the anticipated scenarios caused by climate change. According to the experts [6,7], it is estimated that in regions located in the western Mediterranean, there will be a rise in temperature and an increase in the frequency of extreme events, as well as a decrease in precipitation. These new 
The $1^{\text {st }}$ International Electronic Conference on the Hydrological Cycle (CHyCle-2017), 12 - 16 November, 2017 ; Sciforum Electronic Conference Series, Vol. 1, 2017

scenarios highlight the need for a change in the water policy that promotes the incorporation of new sources, such as non-conventional sources and the implementation of sustainable solutions.

Periods of rapid and disorderly urban growth that have greatly altered the water flows of the area have been recorded in the majority of these regions of the Spanish Mediterranean. This growth has been favoured by stages of economic prosperity and a flexible urban policy [8]. Not only have they directly influenced the increase in the population of the area, but they have significantly altered the land uses of populated areas. Large tracts of land have become urbanized [9]. These important land transformations that have been recorded in Spain since the 1990s have affected the urban environment in particular and, as aforementioned, these have intensified on the Mediterranean coast [3]. According to Greenpeace [10], in the Valencian Community the artificial surface area between 1987 and 2005 practically doubled, from 15,000 to almost 30,000 hectares, with an increase in the number of houses built between 1996 and 2006 going from 30,000 to 92,000 [11]. A clear example of this can be observed in the province of Alicante, which, between 1997 and 2008, was the third Spanish province in terms of the number of houses built [12]. Throughout the last few decades, various processes of concentration, dispersion and the creation of new urban nuclei can be distinguished. These transformations are different to the traditional compact settlement model of the mid-twentieth century [13]. The impervious surface of the land makes it impossible for the water to infiltrate it and this means that the runoff water cannot be absorbed, thus increasing the associated environmental problems (floods and pollution).

In view of the aforesaid, obviously urban areas have had to adapt their hydraulic infrastructures to this urban and population growth. Considering the great hydraulic tradition of Spain, several plans of actions have been developed that are associated with the collection and transportation of water, which to a great extent, for several decades, have satisfied demands, such as the construction of dams and reservoirs [14], the transfers between basins or running underground aquifers. But these measures are now insufficient to meet urban and agricultural demands. This situation is aggravated by the effects of climate change. That is why it has been necessary to seek new supply sources, such as unconventional resources (desalination and the reuse of reclaimed water) [15], and promote sustainable urban measures to increase resilience and create smart and sustainable cities.

The incorporation of new water supply sources in urban environments with fast-growing tourism has been a constant practice during the last decade on the Mediterranean coast of Spain [16]. The reuse of treated flows for agricultural irrigation has been popular for decades. Despite being a more recent practice in Spain, desalination, has gained tremendous value in terms of ensuring human supply. 
The $1^{\text {st }}$ International Electronic Conference on the Hydrological Cycle (CHyCle-2017), 12 - 16 November, 2017 ; Sciforum Electronic Conference Series, Vol. 1, 2017

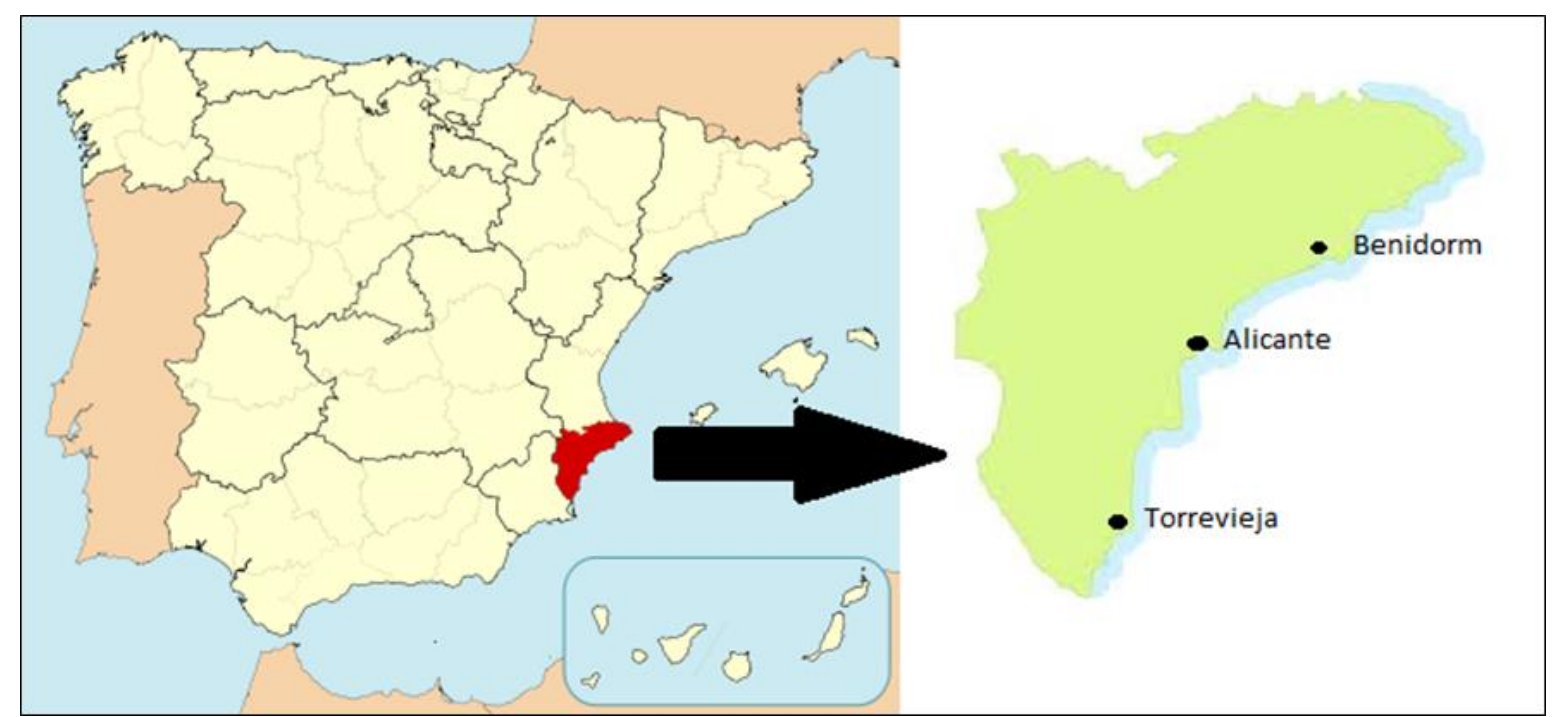

Figure 1. Location of the cases studied.

The objective of this paper is to highlight the various hydraulic measures that have been carried out in cities located on the Mediterranean coast in order to adjust to different scenarios over the years. These adaptive strategies are put into practice through the analysis of flow patterns that characterize the hydrosocial cycles of three cities located in the province of Alicante (Alicante, Benidorm and Torrevieja), in south eastern Spain (Figure 1), a region characterized by a serious water shortage that has led to an intensification of these adaptive measures.

\section{Materials and methods}

\subsection{Data collection}

In order to carry out the evolutionary analysis of the flow diagrams in cities located in the Mediterranean area and to exemplify the above in the three case studies, diverse and varied information has been collected. Literature on the evolution of these areas and how they are linked with the water resources throughout history has been consulted. Not only the urban development in recent years, but also the evolution of the supply sources of the different entities involved. Furthermore, several entities have been contacted in order to obtain information on the water resources, demands and governance systems of the three case studies. The diagrams have been created using data for the year 2013 because, by then, the models were already consolidated and the largest amount of data could be collected.

At a regional level, for both Alicante and Torrevieja, water management is run by the Mancomunidad de los Canales del Taibilla (MCT), a public entity considered to be one of the largest national hydraulic complexes [17]. In the case of Benidorm, the Consorcio de Aguas de la Marina Baja (CAMB) is in charge of the water management. Data has been collected from these two entities, both qualitatively and quantitatively, on the source of the water they supply (groundwater, surface water, Tajo-Segura transfer and desalinated water), the volumes of each one of them and its catchment, production, regulation and distribution infrastructures.

On the local level, in each of the cities the water cycle is managed by a company, or rather a different business model. In Alicante Aguas Municipalizada de Alicante, a mixed company (City Council and Hidraqua) is in charge of the water cycle and it has provided information on the domestic supply and consumption for this study, along with data on the management of regenerated water in the urban environment. The private company that is in charge of water management in the city of Benidorm is Hidraqua, which has provided information about urban consumption. And finally the water management company in Torrevieja is Aguas del Arco 
The $1^{\text {st }}$ International Electronic Conference on the Hydrological Cycle (CHyCle-2017), 12 - 16 November, 2017; Sciforum Electronic Conference Series, Vol. 1, 2017

Mediterráneo (AGAMED), a mixed company (city council and Hidraqua), which has also provided data on management and supply at an urban level.

The management of waste water in the Valencian Community, to which the province of Alicante belongs, is carried out by the Public Entity of Wastewater Sanitation of the Valencian Community (EPSAR), thanks to which, in addition to the information on the types of treatment of the different plants involved, the magnitude of the flows treated and reused by each of the residual plants of these cities could also be determined.

\subsection{Adaptation strategies}

Given the physical-ecological characteristics of Spain, over the centuries a large number of infrastructures have been built to try and store water. An example of this is the large number of dams and reservoirs, some 1200, which are distributed throughout Spain [18], whose storage capacity has reached about 56,000 $\mathrm{hm}^{3}$ [19]. Among other functions, this has helped regulate and supply water to the cities. But in some regions the creation of reservoirs was not enough, because their rivers did not have the necessary flows to cover the demand of the area. For this reason, canals were built that connected both intra-regional and interregional basins, their maximum exponent was reached with the Tajo-Segura transfer. This canal connects the Tagus basin, located in the centre of the peninsula, with the Segura basin, in the southeast of Spain [20]. Thanks to this transfer, the regions that make up the Segura basin, an area characterized by its structural water shortage and reduced rainfall, was able to supply both their populations and large cultivated areas (which require around $80 \%$ of the demand of the basin). These water regulation and transport systems have been the basis of the Spanish model for decades. However, in some regions, such as those located on the Mediterranean coast, in the late 1990s the combination and mixing of surface water (own and external) and the groundwater was not enough, given the continuous increase in demand, to satisfy them. It was then necessary to search for new supply sources, as a complement to conventional resources [21]. This action is included in the so-called hydraulic paradigm, where demands are satisfied by increasing the supply [22]. The incorporation of non-conventional resources, desalination and the reuse of reclaimed water, depending on the quality required for each one of the uses, has meant that the highest quality water can be set aside for human consumption, and the lower quality water can be used for other activities that are less demanding, such as agriculture [4]. An era has now begun in which, thanks to the progress made in water treatment, "à la carte" water can be created, with water management policies that are based on the concept of "fit for purpose" [23].

Thanks to the reuse, a practice that entails a series of economic and environmental advantages [24], higher quality water volumes can be released for priority uses, with this unconventional resource being used in compliance with the R.D. 1620/2007, mainly for the agricultural irrigation of certain crops and, to a lesser extent, for certain urban, recreational and industrial uses. The restrictive requirements of this regulation, the high salinity of some effluents, as well as the social reluctance to face possible sanitary problems [25, 26]; limit the expansion of this practice for some uses [4]. The reuse of regenerated water has been developed more in regions with severe water shortages, such as the Mediterranean arc and the Balearic Islands. These regions have pioneered the use and development of this practice. In spite of this, all the water in question is not reused [2]. Moreover, recycling other waters, such as rainwater or grey water, also provides additional and significant input on a local level [26]. 
The $1^{\text {st }}$ International Electronic Conference on the Hydrological Cycle (CHyCle-2017), 12 - 16 November, 2017; Sciforum Electronic Conference Series, Vol. 1, 2017

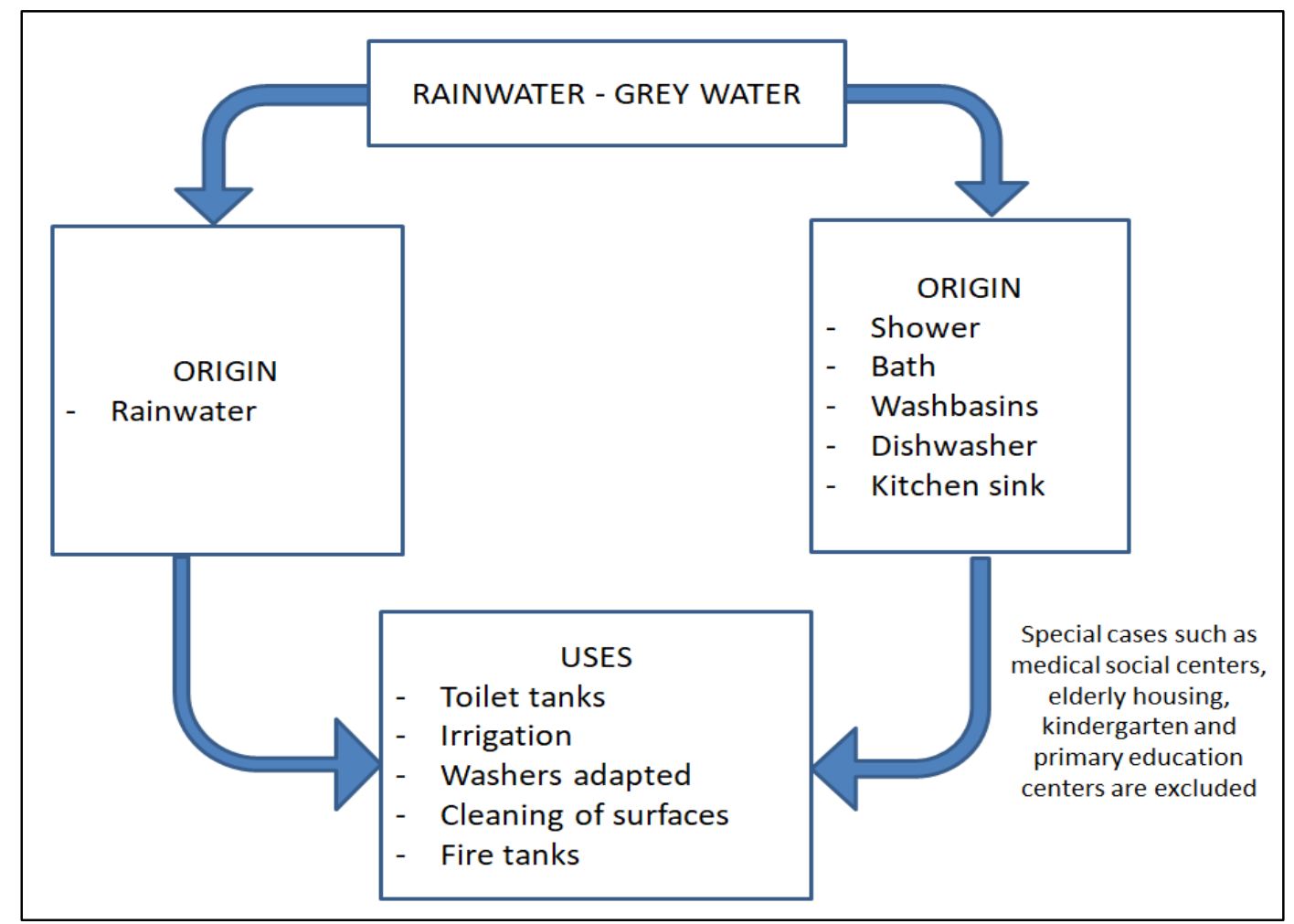

Figure 2. Origin and uses of rainwater and grey water [27, 28].

Although the reuse of wastewater is considered to be the most popular measure with the greatest potential, recycling other waters such as grey water and rainwater is also worthwhile, because on a smaller scale it can promote the overall use of water resources available and the sustainable management of the resource. These practices are still embryonic in Spain, but in other European countries their practice is widespread, as government agencies subsidize them. Studies carried out on this matter [27, 29]. show that reusing this water can save up to $40 \%$ of the household water consumed (Figure 2); it has replaced better quality water that was previously used for flushing the toilet or watering gardens. However, to achieve this objective, a legal framework is required to regulate the use and the implementation of grey water and storm water reuse systems, both on a European level and on a national or regional level, which does not exist at present.

The advantage of desalination is that its source, namely the sea, can be considered to be inexhaustible, which considerably increases the contributions to the system. However, the high energy and economic costs (especially during OI, the most widespread technique in Spain) make this resource too expensive for some sectors, such as agriculture [30]. In Spain, desalination was presented as being the solution to the country's water problems, promoting the construction of a large number of plants along the Mediterranean arc under the protection of the A.G.U.A Program. [31]. The demand estimates for the watersheds on which this program was based have never been met and most of the time the majority of plants do not work at full capacity [32], although their activity increases in periods of drought, which is what is happening in 2017. Several measures are being taken to reduce energy consumption, such as the incorporation of energy recovery devices or latest generation membrane systems [33]. In this way the resource would be economically accessible to a larger number of users, but while this is not possible, desalination ensures human supply in the event of drought or an emergency, and it is therefore considered to be a strategic resource [15].

The MCT, created in 1927, is a perfect example of this diversification of resources, as it distributes water from the Taibilla River, the Tajo-Segura transfer, the desalination plants it has in the Segura basin and, if there is an emergency, other waters such as those coming from the so-called 
The $1^{\text {st }}$ International Electronic Conference on the Hydrological Cycle (CHyCle-2017), 12 - 16 November, 2017; Sciforum Electronic Conference Series, Vol. 1, 2017

"dry wells" of the Calasparra syncline. This fact is made clear in Figure 3, which illustrates the variability of each of the sources according to the circumstances and the needs for each year.

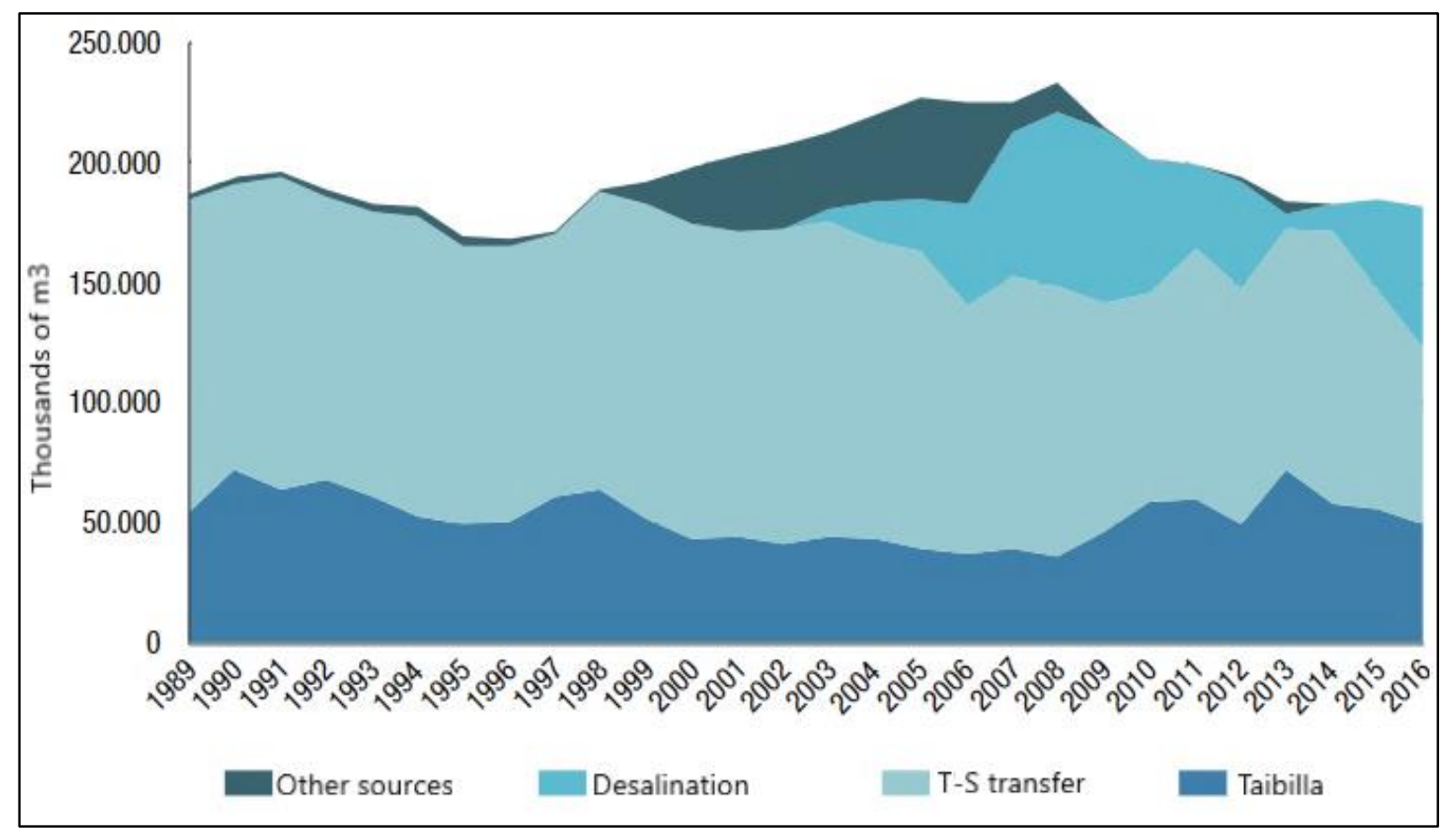

Figure 3. Origin of the different sources of the MCT.

Furthermore, various measures have been taken to optimize the management of water resources in these cities. An example of this is the sustainable urban drainage systems which, in addition to mitigating the effect of flooding, help reduce the pollution they produce and make it possible to reuse the rainwater that is collected [34]. Locally, another example would be building new catchment and treatment systems, both grey water and rainwater, to use later on as part of urbanization, as discussed above. The incorporation of this type of resource (rainwater and grey water) would help increase the resilience of these areas in the event of future scenarios of climate change, and also reduce the pressure on water resources.

\subsection{Creating hydrosocial cycles}

Thanks to both the quantitative and qualitative data provided by the actors involved in this process, a hydrosocial cycle model can be created (Figure 4) [16], which has various components of this hybrid system where society and nature closely interact $[35,36]$. To this end, the input in the system must be taken into consideration first. The complexity of these cycles in Spain is mainly associated with the capacity to provide the resources needed to meet the demands by diversifying sources. Initially those known as conventional sources (surface waters and groundwater) were used, but as these contributions have not been enough to cover the increasing demands it has also been necessary to incorporate non-conventional sources, such as re-use and desalination. The amount supplied to the system by each of these sources, which depends on the current availability, helps create a dynamic and adaptive subsystem that can deal with different adverse scenarios. 
The $1^{\text {st }}$ International Electronic Conference on the Hydrological Cycle (CHyCle-2017), 12 - 16 November, 2017 ; Sciforum Electronic Conference Series, Vol. 1, 2017

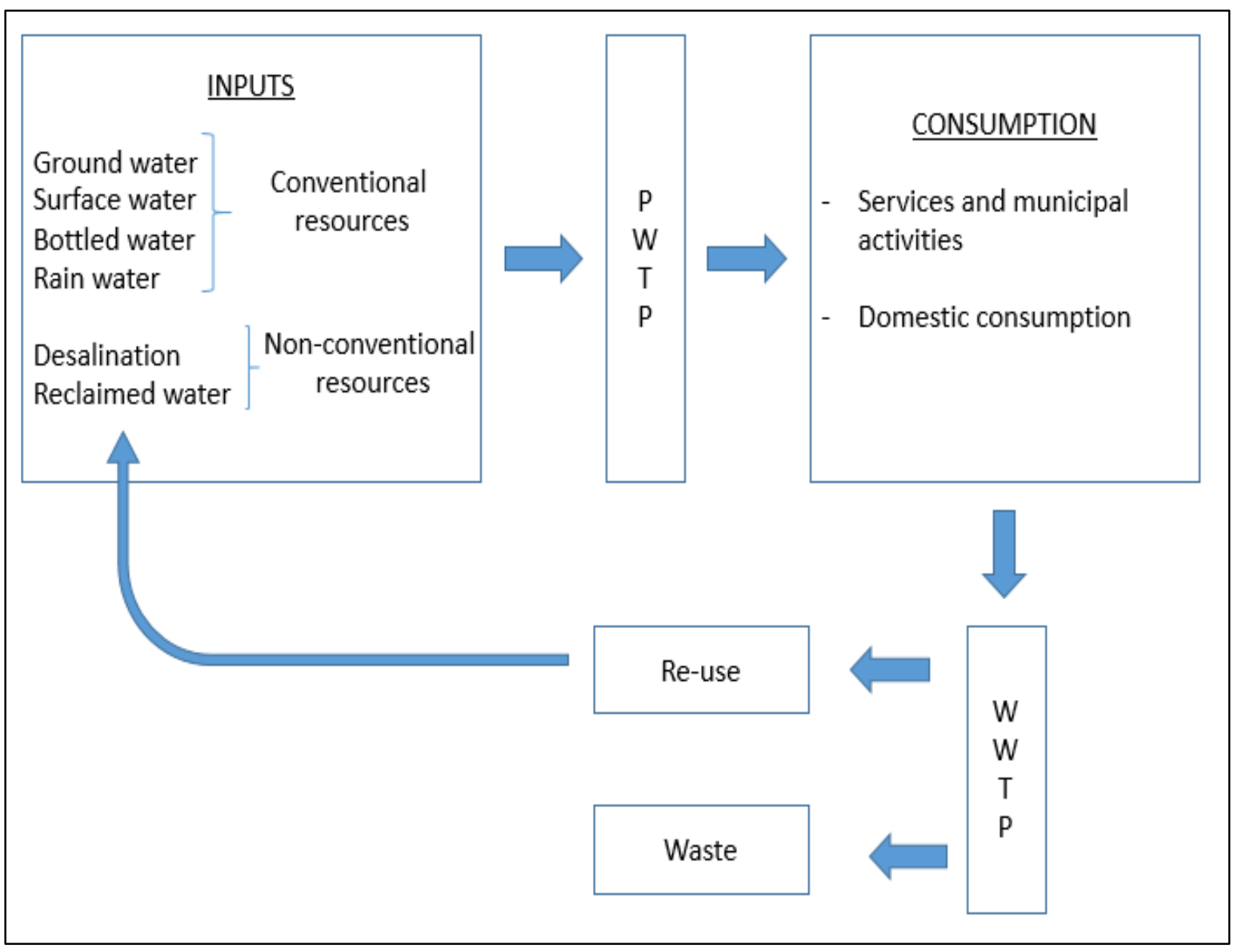

Figure 4. Model to create urban flow charts. Compiled by the author.

All the water sources are treated for domestic use. Then the treated water is distributed to be used in municipal services and activities, hotels (where appropriate) and domestic consumption, which is the one of the most important. After that this water is sent to the treatment plant, along with the runoff water. Once there, it is treated to fulfil the legally established physical, chemical and biological parameters, so that it can be reused. Although some of this treated water is still dumped into rivers or the sea, a certain percentage is reused, mainly for irrigation and for recreational purposes (golf courses). In some cases, this regenerated water is also used for other activities that require low quality water for urban demands, such as the irrigation of green areas or to clean the streets, therefore it goes back into the cycle again. Furthermore, the different action that has been taken in the last few years to optimize the management of all the water resource-related phenomena, from the implementation of sustainable drainage systems to the incorporation of grey water and rainwater collection, treatment and reuse systems in buildings or housing estates must be taken into account.

This model can be used and adapted for all cities and at different levels of work, by incorporating the special features that characterize and differentiate certain urban spaces from others. The hydrosocial cycle of a city, which combines the flow of water within a city with the social, economic or political aspects that influence it, highlights the complexity of these systems, especially in areas where water is scarce such as those in the Mediterranean part of Spain.

\section{Results and discussion}

After a theoretical analysis of the components that make up the hydrosocial cycles, this data is extrapolated and applied to three cities of the province of Alicante. Each one is for a different urban model, which shows that these flow diagrams are flexible and can adapt to the situations that 
characterize each city. These flow diagrams not only have provided for the processes that water undergoes in the city, but also the management of these waters. The entities involved in each of the processes are identified by a colour system that is detailed in the legend. The volumetric quantification of the resource from each of the sources or types of treatment, as well as the contributions of rainwater and its interaction with the urban environment have also been incorporated, wherever possible. In this way the diagram acquires a quantitative component that helps show the magnitude of each of its components. The key components of these adaptive measures have been highlighted with a red circle on the diagrams to demonstrate their importance and significance in the evolution of hydrostatic cycles of these cities.

\subsection{The case of Alicante}

Alicante is a city of services, although in the coastal areas it is also a place of tourist-residence. After analyzing the flow diagram created using the data obtained for the year 2013 (Figure 5), the diversification of sources is clear: surface water (both the Taibilla river and those that arrive through the Tajo-Segura transfer), underground aquifer water located in the inland area of the province and desalinated water from the two plants located in this city.

This city has also encouraged the use of regenerated water thanks to the Reuse Master Plan (2002-2003). Through this plan a double distribution network is being created through which regenerated water can reach all parts of the city to cover different urban demands [37]. Currently, more than $70 \%$ of the green areas in this city are irrigated with reclaimed water. Likewise, intakes have been created that can be accessed by private users, as is the case of many single-family dwellings, whose gardens are already irrigated with regenerated water [4]. Water intakes have also been set up in different parts of the city for trucks that clean the streets. Moreover, initiatives have been promoted to mitigate the floods generated by heavy rainfall events. One example is the building of the "San Gabriel" anti-pollution tank, which can store up to $1.1 \mathrm{hm}^{3}$. Secondly, "La Marjal" natural marsh flooding park, with a storage capacity of up to $45,000 \mathrm{~m}^{3}$. Although the latter was not built until 2015, it has been included in the diagram because this type of initiative can have a significant effect on the urban water flows. These two infrastructures are not only considered to be mitigation measures in the event of heavy rainfall events (a situation that is expected to get worse as a result of climate change), but they are also an option to reuse (after passing through the treatment plant) effluents that were previously wasted. 
The $1^{\text {st }}$ International Electronic Conference on the Hydrological Cycle (CHyCle-2017), 12 - 16 November, 2017; Sciforum Electronic Conference Series, Vol. 1, 2017

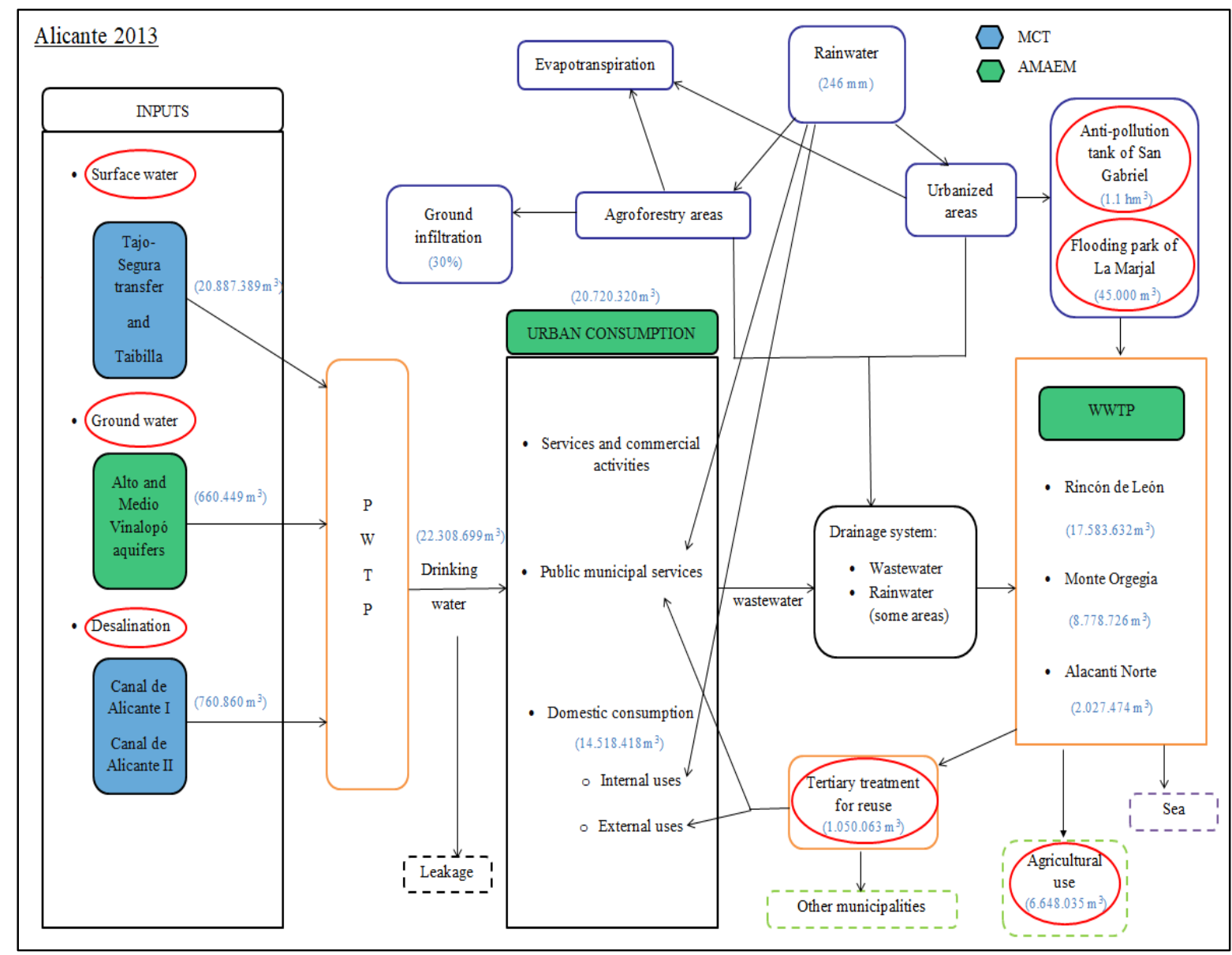

Figure 5. Flow diagram of the city of Alicante in 2013. Compiled by the author.

\subsection{The case of Benidorm}

Benidorm is a clear example of a tourist city predominated by hotels [38]. This tourist resort [39] has one of the most efficient drinking water management systems in Spain, both in times of high and low supply. This is the result of a complex configuration where the conventional source diversification strategy is consolidated by the reuse of wastewater and it is linked to the city's compact and vertical urban nature [40]. The key to the success of this exemplary and unique model established in this city, and its overall use of water resources, lies in the exchange of wastewater treated by white water. The irrigators, who hold the concessions of most of these waters, reached an agreement with the CAMB through which this groundwater was exchanged for reclaimed waters, when necessary, which means that the former can be used for urban supply and the latter mainly for agricultural irrigation [41,42]. Due to the high salinity of the effluent produced by the secondary treatment, a desalination plant has had to be incorporated to be able to adapt the conductivity according to the parameters required for its subsequent use in agricultural irrigation. As shown in the diagram (Figure 6) the system receives both surface water and groundwater. In the event of an emergency water can be supplied through the Rabasa-Fenollar-Amadorio connection [2]. Initially water from the MCT could be used, and since 2015 water from the desalination plant of Muchamiel, located next to Alicante. 
The $1^{\text {st }}$ International Electronic Conference on the Hydrological Cycle (CHyCle-2017), 12 - 16 November, 2017; Sciforum Electronic Conference Series, Vol. 1, 2017

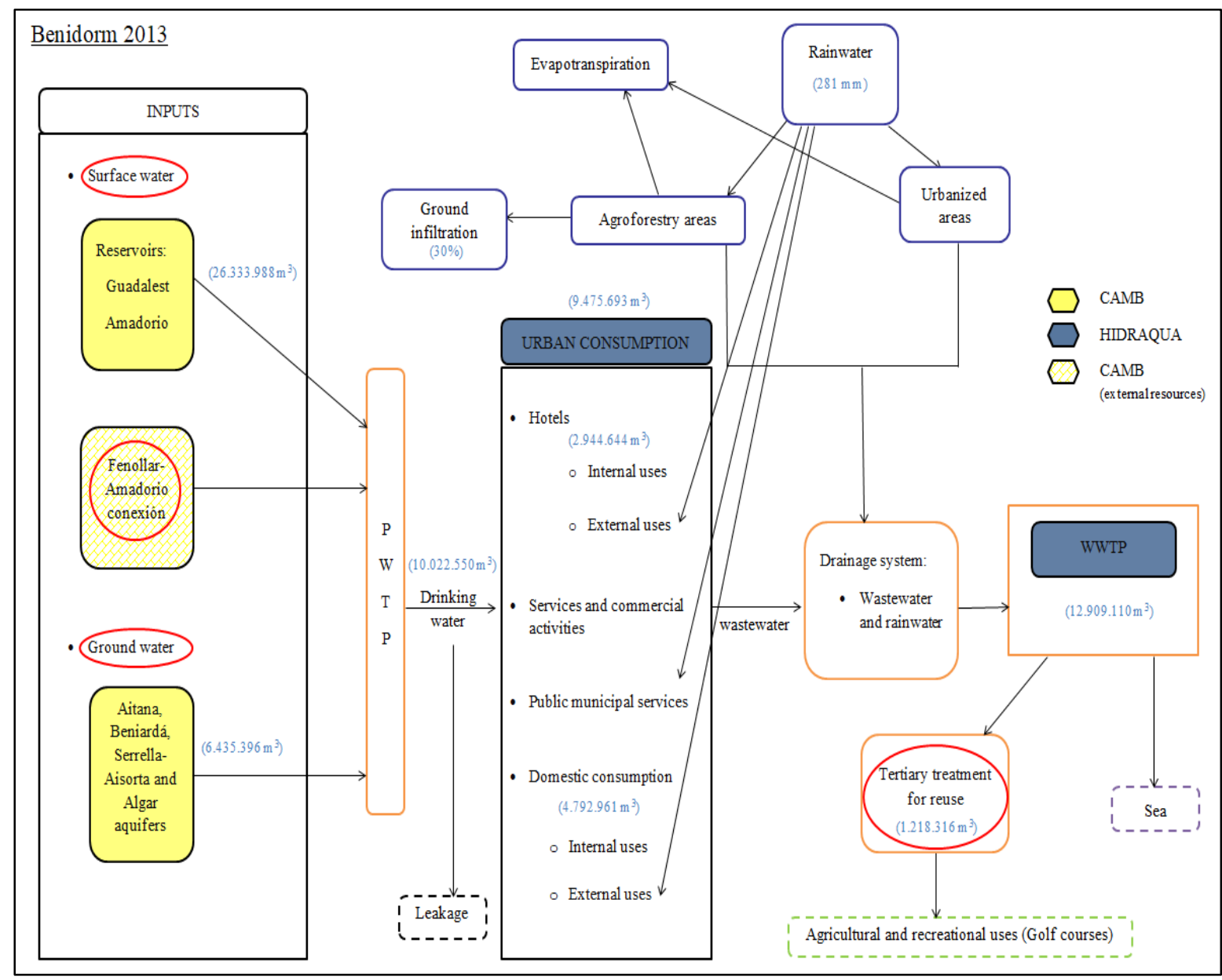

Figure 6. Flow diagram of the city of Benidorm in 2013. Compiled by the author.

\subsection{The case of Torrevieja}

Torrevieja is a city where the so-called residential tourism predominates, as demonstrated by the high percentage of second homes in its housing sector because, according to data from the National Statistics Institute (Census 2011), second homes stand for $67 \%$ of the housing stock in this city. It is worth pointing out that more than half of the population on the census are foreign residents, which highlights the importance of tourism here. This is a major challenge in terms of water management seeing as second homes are mainly occupied during the summer season, therefore the population of this tourist resort at that time of the year can triple. The treatment plants have adapted to the distribution system over the years to cope with these peaks in supply. Another factor that makes management difficult is the fact that the greatest increase in demand is generated when the contributions are lower.

Torrevieja, like Alicante, receives water from the MCT (desalinated plants located in San Pedro del Pinatar (Murcia) and superficial sources). One of the peculiarities to be highlighted in the flow diagram of this city (Figure 7 ) is the fact that $100 \%$ of regenerated water is reused for agriculture [16]. In order to do this, the effluent from the secondary treatment undergoes a tertiary treatment (ultraviolet filtration), which provides the regenerated water that is suitable for its new use. There is also a private desalination plant, located in the vicinity of this city and in the event of an emergency it can provide water to the MCT, which is what is happening in 2017. 
The 1 $1^{\text {st }}$ International Electronic Conference on the Hydrological Cycle (CHyCle-2017), 12 - 16 November, 2017; Sciforum Electronic Conference Series, Vol. 1, 2017

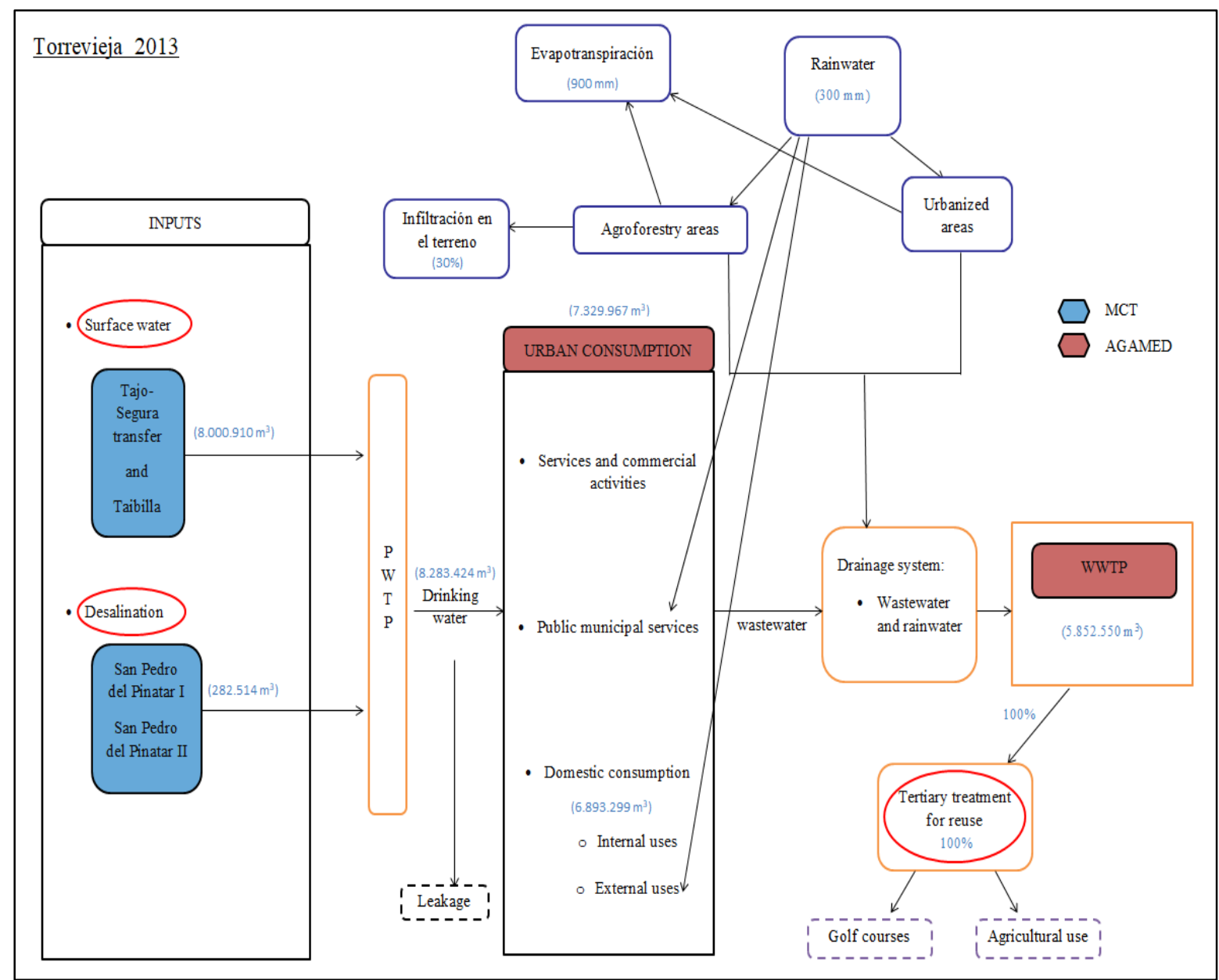

Figure 7. Flow diagram of the city of Torrevieja in 2013. Compiled by the author.

\subsection{Comparative between cases}

The gradual incorporation of the different sources of supply has been the key to the hydrosocial cycles of these cities being able to adapt (Table 1). Each of the three examples, with different urban models, has been able to adjust to the increasing demands by diversifying sources and incorporating unconventional resources, such as desalination and reuse.

Table 1. Chronological incorporation of supply sources

\begin{tabular}{|c|c|c|c|c|c|c|}
\cline { 2 - 7 } \multicolumn{1}{c|}{} & $\begin{array}{c}\text { Ground and } \\
\text { Surface water }\end{array}$ & MCT & CAMB & $\begin{array}{c}\text { Tajo-Segura } \\
\text { Transfer }\end{array}$ & Desalination & Reuse \\
\hline \hline Alicante & $\mathrm{X}$ & 1958 & - & 1979 & 2003 & 2002 \\
\hline Benidorm & $\mathrm{X}$ & - & 1977 & $\begin{array}{c}1997 \\
\text { (Emergency) }\end{array}$ & $\begin{array}{c}2016 \\
\text { (Emergency) }\end{array}$ & $90 \mathrm{~s}$ \\
\hline Torrevieja & $\mathrm{X}$ & 1972 & - & 1979 & 2003 & 1980 \\
\hline
\end{tabular}

Alicante, with an urban-residential model, includes the desalinated water in its urban supply thanks to the flows received from the MCT. In 2015, it reused almost 35\% of the volume treated. These waters were used for agricultural irrigation and for urban activities (irrigation of public and 
The $1^{\text {st }}$ International Electronic Conference on the Hydrological Cycle (CHyCle-2017), 12 - 16 November, 2017 ; Sciforum Electronic Conference Series, Vol. 1, 2017

private green areas and washing the streets) thanks to the double network of regenerated waters, which is being developed in the city. One special feature about Benidorm, a tourist model that is predominated by the hotel industry, is that the white water is exchanged for regenerated water between agricultural and urban uses during drought situations. Although this city does not incorporate constant desalinated flows, it is connected to the desalination plant of Mutxamel through which it can receive this resource in the event of a drought or an emergency. Torrevieja, a tourist model, where second homes predominate, receives desalinated flows through the volumes supplied by the MCT, as well as Alicante. However, one point that must be highlighted here is that this city reuses $100 \%$ of the flows treated for agricultural use and to water golf courses.

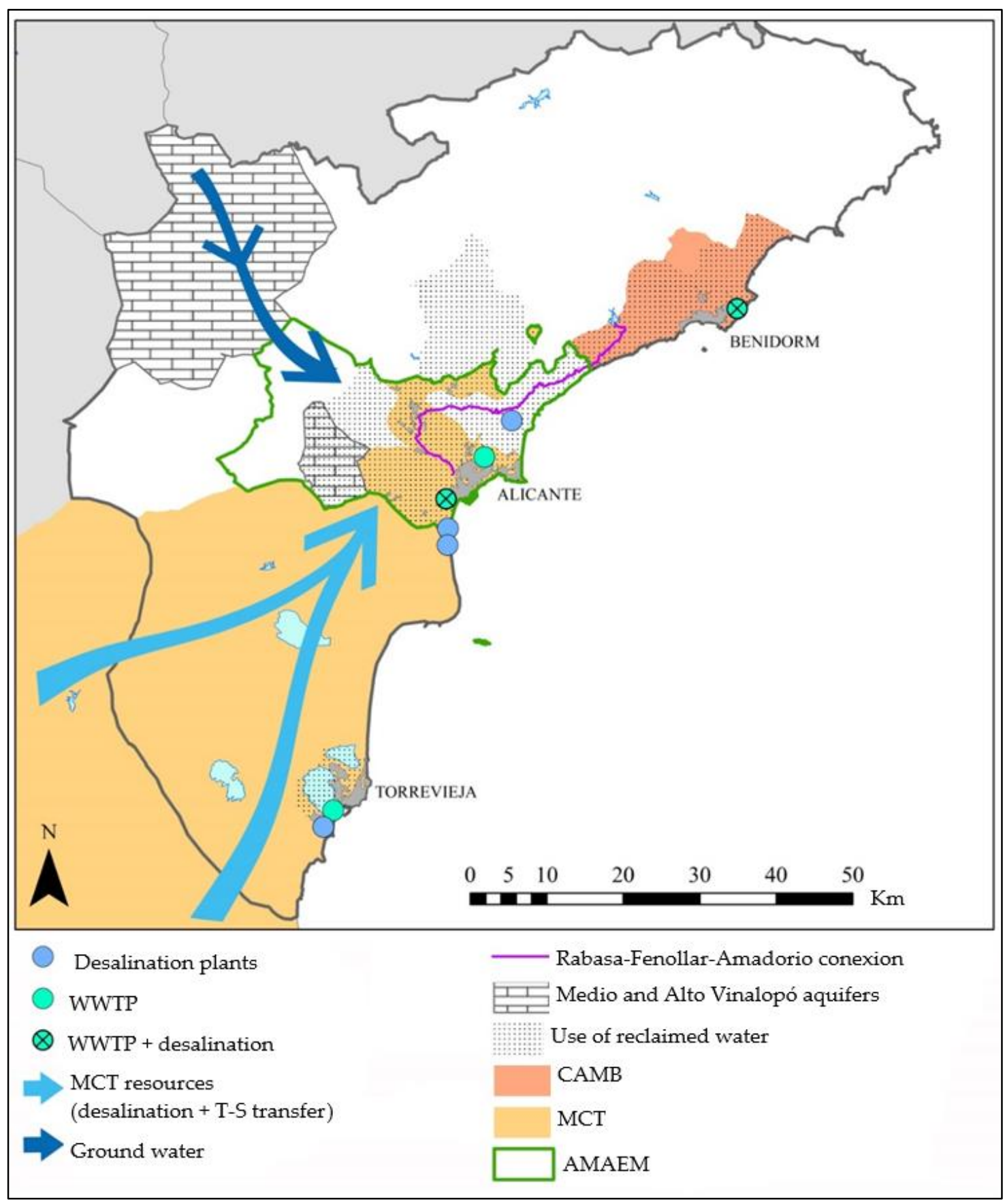

Figure 8. Diagram of the distribution, management and use systems linked to case studies in 2017. Compiled by the author. 
The $1^{\text {st }}$ International Electronic Conference on the Hydrological Cycle (CHyCle-2017), 12 - 16 November, 2017 ; Sciforum Electronic Conference Series, Vol. 1, 2017

This complex situation is observed in the province of Alicante, where the resources come from different intraregional and interregional sources and the water governance also varies according to the city as shown schematically in Figure 8.

\section{Conclusions}

Over the years the hydrostatic cycles of the cities have had to adapt to the increase in demand to be able to cover it. This fact, which in itself is a challenge, becomes more complex in regions and municipalities that are characterized by water shortages, such as on the Spanish Mediterranean coast. The flow diagrams of cities with water shortages, which are likely to worsen in the future as a result of the effects of climate change, highlight the importance of diversifying sources in these regions. An important point has been the incorporation of unconventional resources, desalination and water reuse. Desalination has made it possible to ensure supply in some regions, despite its high price, while reuse has meant that higher quality water can be set aside for priority uses, such as human supply, by using lower quality water, such as reclaimed water for agricultural or recreational activities. Furthermore, an emerging trend associated with the introduction of sustainable measures is observed in the management of urban water associated with the use of rainwater.

The urban flows model is applied in 3 cities of the province of Alicante, to corroborate their adaptability to the circumstances and the different urban models. They show the adaptive measures that the system has taken to meet the water demands and to be able to cope with future scenarios. Moreover the diversification of sources and the incorporation of non-conventional resources are highlighted as being key elements.

Acknowledgments: This paper is a result of a pre-doctoral fellowship awarded by Ana Arahuetes of the Researcher Training National Program for Scientific Research, Development and Technological Innovation Research (FPI - BES-2013-066273) and it is included in the research project "Use and Management of non-conventional water resources on the coast of the regions of Valencia and Murcia as a drought adaptation strategy"(CSO2015-65182-CS-2-P) funded by the Ministry of Economy and Competitiveness.

Author Contributions: All authors have contributed equally.

Conflicts of Interest: The authors declare no conflict of interest.

\section{Abbreviations}

The following abbreviations are used in this manuscript:

AGAMED: Aguas del Arco Mediterráneo

MCT: Mancomunidad de los Canales del Taibilla

CAMB: Consorcio de Aguas de la Marina Baja

AMAEM: Aguas Municipalizadas de Alicante Empresa Mixta

EPSAR: Entidad Pública de Saneamiento de Aguas Residuales de la Comunidad Valenciana

PWTP: Potable Water Treatment Plant

WWTP: Waste Water Treatment Plant

\section{References}

1. Rico, A.M.; Olcina, J.; Paños, V.; Baños, C. Depuración, desalación y reutilización de aguas en España. Oikos Tau, Barcelona, 1998; 255 p.

2. Rico, A.M., Arahuetes, A., Morote, A.F. Depuración y reutilización de aguas residuales regeneradas en las regiones de Murcia y Valencia". In Paisaje, cultura territorial y vivencia de la Geografía. Libro Homenaje al profesor Alfredo Morales Gil; Vera Rebolledo, J.F.; Olcina, J.; Hernández, M. (eds), Ediciones de la Universidad de Alicante, 2016; pp. 1169-1202.

3. Hernández, M. Análisis de los procesos de transformación territoriales en la provincia de Alicante (1985-2011) y su incidencia en el recurso hídrico a través del estudio bibliográfico. Documents d'Anàlisi Geográfica, 2013, 59(1), pp. 105-136. 
The $1^{\text {st }}$ International Electronic Conference on the Hydrological Cycle (CHyCle-2017), 12 - 16 November, 2017; Sciforum Electronic Conference Series, Vol. 1, 2017

4. Arahuetes, A. Presente y pasado de la reutilización, una práctica clave en regiones con estrés hídrico. In Nuevas aportaciones en la investigación en humanidades; Cutillas, E. (ed.); Universidad de Alicante, 2017, pp. 21-32.

5. ASAJA, Agua para garantizar la agricultura en la provincia de Alicante, Cadena SER. Available online: http://cadenaser.com/emisora/2017/03/07/radio_elda/1488906168_288172.html (accessed on 09/07/2017)

6. AEMET, Agencia Estatal de Meteorología, 2015. Proyecciones Climáticas para el siglo XXI en España. Available online: $\mathrm{http}: / /$ www.aemet.es/es/serviciosclimaticos/cambio climat (accessed on 13/02/2017)

7. IPCC, Intergovernmental Panel on Climate Change 2014. Climate Change 2013 and climate change 2014 (3 vols.). Available online: http://www.ipcc.ch/ (accessed on 23/08/2017)

8. Morote, A.F.; Hernández, M. Población extranjera y turismo residencial en el litoral de Alicante (1960-2011): repercusiones territoriales. EURE, 2016, Vol. 41, no 126, pp. 55-76.

9. Fernández, S.; Barrado, D.A. El desarrollo turístico-inmobiliario de la España mediterránea e insular frente a sus referentes internacionales (Florida y la Costa Azul): un análisis comparado". Cuadernos de Turismo, 2011, no 27, pp. 373-402.

10. GREENPEACE (2010): «Destrucción a toda costa 2010». Available online:: http://www.greenpeace.org/espana/es/reports/100709-04/ (accessed on 14/10/2017)

11. Larrabeiti, J.J. Producción de nuevas "naturalezas urbanas" y sus consecuencias sobre el consumo de agua en Alicante. Investigaciones geográficas, 2012, nº 58, pp. 143-170.

12. Hernández, M.; Saurí, D.; Morales, A. Auge y caída de nuevas naturalezas urbanas: plantas ornamentales y expansión turístico-residencial en Alicante. Boletín de la Asociación de Geógrafos Españoles, 2015, nº 68, pp. 129-157.

13. Salvati, L. y Sabbi, A. Exploring long term land cover changes in an urban region of southern Europe. International Journal of Sustainable Development and World Ecology, 2011, Vol. 18, no 4, pp. 273-82.

14. García, D. Análisis energético de los recursos hídricos en España. Trabajo Fin de Grado, 2016. Universidad Pontificia de Comilla, 93 p.

15. March, H.; Saurí, D.; Rico, A. M. The end of scarcity? Water desalination as the new cornucopia for Mediterranean Spain. Journal of Hydrology, 2014, Vol. 519, Part C, pp. 2642-2641.

16. Arahuetes, A.; Villar, R.; Hernández, M. El ciclo hidrosocial en la ciudad de Torrevieja: retos y nuevas tendencias, Revista de Geografía Norte Grande, 2016, nº 65, pp. 109-128.

17. Olcina, J.; Rico , A.M. La Mancomunidad de los Canales del Taibilla: un ejemplo de cooperación municipal surgido de una necesidad. In Gobernanza territorial en España. Claroscuros de un proceso a partir del estudio de casos; Romero, J.; Farinos, J. (eds.). Valencia, Publicaciones de la Universidad de Valencia, 2006, pp. 347-374.

18. Juarez, C. Los desafíos del agua. La producción eléctrica como factor de desequilibrio económico regional. In Paisaje, cultura territorial y vivencia de la Geografía. Libro Homenaje al profesor Alfredo Morales Gil; Vera Rebolledo, J. F.; Olcina, J.; Hernández, M. (eds.). Ediciones de la Universidad de Alicante, 2016, pp. 1121-1152.

19. Rico, A.M. Sequías y abastecimientos de agua potable en España. Boletín de la Asociación de Geógrafos Españoles, 2004, no 37, pp. 137-181.

20. MCT, Mancomunidad de los Canales del Taibilla. Gestión del servicio 2013, 48 p.

21. March, H.; Hernández, M.; Saurí, D. Assessing domestic water use habits for more effective water awareness campaigns during drought periods: a case study in Alicante, eastern Spain. Natural Hazards and Earth System Sciences, 2015, nº 15, pp. 963-972

22. Saurí, D.; Del Moral, L. Recent development in Spanish water policy. Alternatives and conflicts at the end of the hydraulic age, Geoforum, 2001, 32(3), pp. 351-362.

23. Morote, A.F.; Hernández, M. El uso de aguas pluviales en la ciudad de Alicante. De viejas ideas a nuevos enfoques. Papeles de Geografía, 2017, nº63 (in press).

24. Melgarejo, J. Efectos ambientales y económicos de la reutilización del agua en España. Clm.economía, 2009, n15, pp. 245-270.

25. Baeza, J. Reutilización de aguas residuales para riego. Trabajo Fin de Máster en Gestión Sostenible y Tecnologías del Agua. Universidad de Alicante, 2009.

26. March, H.; Hernández, M.; Saurí, D. Percepción de recursos convencionales y no convencionales en áreas sujetas a estrés hídrico: el caso de Alicante. Revista de Geografía Norte Grande, 2015, no 60, p. 153-172. 
The $1^{\text {st }}$ International Electronic Conference on the Hydrological Cycle (CHyCle-2017), 12 - 16 November, 2017 ; Sciforum Electronic Conference Series, Vol. 1, 2017

27. Soriano, A. (2012): Reutilización de aguas grises y vertido de aceites usados en la red de evacuación. Jornada sobre gestión de los aceites usados de cocina y su aprovechamiento con fines energéticos en el marco del proyecto OILECO, 2012, Madrid.

28. AQUA España. Guía técnica de aprovechamiento de aguas pluviales en edificios, 2011, 17 p.

29. Domenech, L.; March, H.; Saurí, D. Degrowth initiatives in the urban water sector? A social Multi-criteria Evaluation of non-conventional water alternatives in Metropolitan Barcelona. Journal of Cleaner Production, 2013, no 38, pp. 44-55.

30. Arahuetes, A. Desalinización y energía en España. Situación y perspectivas. El caso del Mediterráneo. In Gestión de recursos hídricos en España e Iberoamérica; Mora, J. (ed.). Pamplona: Editorial ARANZADI, 2015, pp. 529-540.

31. Morote, A.F.; Rico, A.M.; Moltó, E. La producción de agua desalinizada en las regiones de Murcia y Valencia. Balance de un recurso alternativo con luces y sombras. Documents d'Anàlisi Geogràfica, 2017, 63(2), pp. 473-502.

32. Del Villar, A. El coste energético de la desalinización en el Programa A.G.U.A.. Investigaciones Geográficas, 2014, no 62, pp. 101-112.

33. Paulson, L.D. (2015). El mundo de la desalinización crece en el mundo a medida que aumenta su eficiencia. RWL Water web. Available https://www.rwlwater.com/el-uso-de-la-desalinizacion-crece-en-el-mundo-a-medida-que-aumenta-su-efi ciencia/?lang=es (accessed on 2/10/2017)

34. Perales-Momparler, S; Andrés-Doménech, I; Hernández-Crespo, C.;Vallés-Morán, F.; Martín, M; Escuder-Bueno, I.; Andre, J. The role of monitoring sustainable drainage systems for promoting transition towards regenerative urban built environments: a study in the valencian región, Spain. Journal of Cleaner Production, 2017, no 163, pp. S113-S124.

35. Swyngedouw, E. The political economy and political ecology of the hidrosocial cycle. Journal of Contemporary Water Research and Education, 2009, 142(1), pp. 56-60.

36. Linton, J.; Budds, J. The hydrosocial cycle: Defining and mobilizing a relational-dialectical approach to water. Geoforum, 2014, no 57, pp. 170-180.

37. AMAEM, Aguas Municipalizadas de Alicante Empresa Mixta. Informe desarrollo sostenible AMAEM 2015, 314p.

38. Baños, C.J. Modelos turísticos locales. Análisis comparado de dos destinos de la Costa Blanca. Investigaciones Geográficas, 1999, no 21, pp. 35-57.

39. Olcina, J.; Baños, C.J.; Rico, A.M. Medidas de adaptación al riesgo de sequía en el sector hotelero de Benidorm", Revista de Geografía Norte Grande, 2016, nํ65, pp. 129-153.

40. Rico, A.M.; Olcina, J.; Baños, C.J. Competencias por el uso del agua en la provincia de Alicante: experiencias de gestión en la amortización de usos urbano-turísticos y agrícolas. Documents d'Anàlisis Geogràfica, 2014, Vol. 60, nº3, pp. 523-548.

41. GIL, A. Optimización de recursos hídricos y armonización de sus usos: el Consorcio de Aguas de la Marina Baja. Investigaciones Geográficas, 2010, nº 51, pp. 165-183.

42. IUACA, Instituto Universitario del Agua y Ciencias Ambientales. Desde un Benidorm abastecido con buques-tanque hasta un modelo único de gestión integral del agua, iagua 2016. Available online:: http://www.iagua.es/noticias/espana/iuaca/16/03/07/benidorm-abastecido-buques-tanque-modelo-unicogestion-integral-agua (accessed on 07/04/17)

(c) 2017 by the authors; licensee MDPI, Basel, Switzerland. This article is an open access article distributed under the terms and conditions of the Creative Commons by Attribution (CC-BY) license (http://creativecommons.org/licenses/by/4.0/). 